УДК 821.161.2.09 П. Куліш

Дмитренко Вікторія, доктор філологічних наук, професор, професор кафедри української та світової літератур Криворізький державний педагогічний університет

\title{
РЕЦЕПЦІЯ СХОДУ У ТВОРЧОСТІ ПАНТЕЛЕЙМОНА КУЛІША
}

\begin{abstract}
У статті акцентуетъся увага на актуальності в наш час творів П. Куліша східнӧ тематики, які сповнені утвердження любові до ближнъого й гармонї̈ між людъми різних віросповіданъ. Твори «Магомет $i$ Хадиза», «Маруся Богуславка» та ін. стали своерідною квінтесенціею пошуків П. Куліша щодо доведення близъкості Корану й Біблї, репрезентацією представлених у них загальнолюдсъких домінант. Автор статті зазначае, що писъменник одним із перших відкрив християнсъкій Украӥні етичні й кулътурні цінності ісламсъкого світу. Поема «Магомет $i$ Хадиза» $е$ своерідною спробою донести до українсъкого читача основні ідей ісламу, у ній П. Куліш підкреслюе $\ddot{x}$ спілъність з християнсъкими. Важливим у творі e той факт, що носієм справедливості й добра є жінка, дружина Магомета Хадиза. У поемі «Маруся Богуславка» писъменник поновому переосмислив міжнаціональні взаємини, репрезентувавши християнсъкий світ в образі украӥнки Марусі, а ісламсъкий в образі турка Османа, який заради любові до жінки готовий допомогти т̈̈ рідній країні. У такий спосіб П. Куліш намагаетъся змінити вектор рецепціӥ Сходу украӥниями .
\end{abstract}

Ключові слова: Схід, Коран, Біблія, загалънолюдсъкі uінності.

Dmytrenko V. The Reception of the East in Pavlo Kulish's art.

The article under consideration is focused on the relevance of the works by P.Kulish nowadays, which are full of affirmation of love for one's neighbor and harmony between people of different believes. The works of art, such as "Mahomet and Khadyza", "Marusia Bohuslavka" and others, became the quintessence of Panteleimon Kulish's quest to prove proximity to the Qur'an and the Bible, a representation of the universal dominants provided with them. The author notes that the writer was one of the first who discovered the ethical and cultural values of the Islamic world in Christian Ukraine. The poem "Mahomet and Khadyza" is a kind of attempt to convey to the Ukrainian reader basic ideas of Islam, in which Panteleimon Kulish emphasizes their commonality with the Christian. It is important to note the fact that the bearer of justice and goodness is the woman, Mahomet's wife Khadyza. The writer reinterpreted inter-ethnic relations in a new way in his poem "Marusia Bohuslavka", where the Christian world is depicted through the image of the Ukrainian Marusia, and the Islamic one is of the Turk Osman, who, for the sake of love for a woman, is ready to help her native country. In this way Panteleimon Kulish tries to change the vector of the reception of the East by the Ukrainians.

Key words: the East, the Qur'an, the Bible, universal values. 
192 Літератури світу: поетика, ментальність і духовністъ. 2020. Bип.14

Постановка проблеми. Творчість П.Куліша східної тематики сповнена утвердження любові до ближнього, гармонії й взаєморозуміння між людьми різних віросповідань. Це робить iї актуальною в найскладніші періоди розвитку людства, змушує постійно звертатись до неї, щоразу знаходячи нові смисли. Доробок митця генерує різні, інколи кардинально протилежні ідеї й роздуми, тому його творча постать завжди була в колі зацікавлень багатьох дослідників.

Аналіз останніх досліджень і публікацій 3 теми. Серед перших дослідників творчості П. Куліша імена І. Франка, Б. Грінченка, М. Грушевського, М. Зерова та ін. Із сучасних праць варто виділити грунтовні роботи В. Івашківа і Є. Нахліка, а також керівника Центру дослідження життя і творчості Пантелеймона Куліша при Інституті літератури ім. Т.Г.Шевченка О. Федорука. Проблеми творів східної тематики приділяли увагу Мар'яна й Зоряна Лановик [1], Є. Нахлік [2], Ганни Останіна [3] та ін. Мар'яна й Зоряна Лановик і Ганна Останіна розглянули їх у руслі європейських романтичних домінант, що поєднуються в них з азіатським містицизмом. Є. Нахлік грунтовно дослідив історію створення й художні особливості творів дотичних до ісламської культури. Проте глибина й різновекторність проблеми, порушеної в цих текстах українським письменником ще у XIX столітті провокує нові дослідження.

Мета публікації - розглянути твори П. Куліша східної тематики з точки зору способів репрезентації в них загальнолюдських проблем, порушення яких, на думку письменника, має сприяти миру, злагоді й взаєморозуміння між народами не залежно від будь-яких упереджень.

Виклад основного матеріалу дослідження. Знання мов дали П. Кулішу можливість долучитись до пам'яток культури інших народів, а також перекласти українською перлини світової літератури, збірка «Позичена кобза» є свідченням цього. Він переклав чимало творів Дж. Байрона серед яких «Паломництво Чайльд Гарольда», 15 драм В. Шекспіра (10 із них були видані у Львові з передмовою I. Франка). Письменник активно працював над перекладом Біблії, залучивши до роботи І. Пулюя, проте, на жаль, ми не знаємо повний обсяг зробленої П. Кулішем роботи, адже відомо, що пожежа на хуторі Мотронівка знищила значну частину його рукописів.

Досить логічним є той факт, що саме П. Куліш одним із перших відкрив християнській Україні етичні й культурні цінності ісламського світу. Процес відродження («ан-Нахда»), що почався в арабському світі, з часу появи в Єгипті експедиції Наполеона Бонапарта (1798-1801), 
сприяв проникненню европейських держав на Схід і став поштовхом до активного вивчення історіі, культури й релігї ісламу.

У біографії П. Куліша є інформація про те, що у 1861 році, під впливом активного зацікавлення Європи Сходом, він відвідав Стамбул, захоплювався східними філософськими працями, а саме філософією Ібн Рошда Аверроеса. Тому в поемі «Магомет і Хадиза» чимало східних реалій, які свідчать про заглиблення письменника у світ Сходу, знання ним його специфіки. Так, наприклад, у поемі автор приділяє увагу язичницьким ритуалам, що проходили біля Кааби (священне місце для народів Аравії, що існувало задовго до виникнення ісламу). Там було встановлено 360 ідолів божеств, яким молилися аравійські племена (саме ці ідоли непокоять Магмета (Мухаммеда) у творі). 3 історії відомо, що Мухаммед у 630 році знищив ідолів, залишив тільки двох: Маріам (діви Марії) і Іси (Ісуса). У поемі П. Куліша саме в Каабі Мухаммед висловлює недовіру, щодо божеств, пропонує язичникам здійснити намаз, але його хапають й ведуть на страту як недовірка, і тільки поява Хадизи (Хадіджі) з коштовними дарами рятує йому життя.

Крім поеми «Магомет і Хадиза» до творів східної тематики належить поема «Маруся Богуславка», «Дума про татарина й орапа», а також віршована драма «Байда, князь Вишневецький». Зацікавлення історією та культурою мусульманського світу П. Кулішем у досить зрілому віці дає можливість говорити про те, що «східні поеми» стали квінтесенцією творчих пошуків Куліша. «Вони великою мірою розкривають таємниці його поглядів $i$ водночас творять певний смисловий шифр світоглядних горизонтів, для розкодування якого необхідно вийти за межі раціочентричного аналізу, залучаючи конгеніальний метод герменевтичної інтерпретацї̈ та обираючи відправною точкою близъкий писъменникові східний тип мислення у сприйнятті надскладних явищ, буття - i особистісних (віра, доля, істина), i суспільних (народ, доля нащї, священна історія)» [1, с. 73].

Поема «Магомет і Хадиза» належить до «пізнього» періоду творчості Куліша - написана у 1883 році й того ж року вперше була надрукована у Львові. За своїм віросповіданням П. Куліш був православним християнином, при цьому з повагою ставився до інших віровчень, а тому й хотів відкрити християнській Україні етичні та культурні цінності ісламу. Це одне з надзавдань твору. Сам автор у листі до М.Драгоманова від 22 березня 1883 року повідомивши про задум надрукувати поему східної тематики, зазначає, що вона має стати «прелюдією» цілого циклу творів на цю тему й наголошує, що «не покидаючи рідної Українщини, автор у поезї чужсӧ жизні 
відпочиватиме духом од Польсъко-Єзуӥтсъкого, Москво-Російсъкого $i$ нашого Козако-Украӥнсъкого фанатизму, котрий не дає легко дихати поетовi» $[4$, с. 7$]$.

У поемі виділяємо дві сюжетні лінії, які перемежовуються. Перша пов'язана з історією виникнення ісламу. Це шлях Магомета від убогого сироти до Пророка, засновника світової релігії. Друга - чиста безмежна любов до нього Хадизи, на яку Магомет відповів взаємністю. Це означено у двох епіграфах до твору. Перший - цитата 3 книги американського вченого Д. В. Дрепера «Історія боротьби між вірою і наукою» у якій йдеться про особу самого Мухаммеда і його шанобливе ставлення до Хадизи як до ідеальної жінки. Можна припустити, що саме 3 цього дослідження П. Куліш взяв основну інформацію про мусульманський світ. Другий епіграф доповнюе перший. По суті це гімн коханій жінці, можливо, поема є своєрідним вибаченням П. Куліша перед своєю дружиною. Епіграф має форму монологу в якому Мухаммед, звертається до красуні Аеші (Айші), його другої дружини, розкриваючи свої почуття до Хадизи, яку він уважає ідеальною жінкою: «Я був малий, мізерний $i$ незнаний, - / Вона мене між тисячами вздріла / I золото, й верблюдів каравани, / I всю судъбу мені свою вручила» [5, с. 355].

Сюжет твору частково повторює реальну біографію Магомета, але чимало художніх дописів й описів сповнюють поему. Так, «задумливопечальна» Аравія постає в рецепції П. Куліша як фундаментальний розум, бо розташована на камені. Камінь і піски - це своєрідний кордон до тієї Аравії, що «Над морем, як над дзеркалом, схилиласъ. / Там раєм пишним ти, барвистим зеленіла, / Про твій оазис мореходи знали, / До тебе паруси носили їх, мов крила; / Щасливою вони тебе прозвали / I про тебе казки дивовижсні казали» [5, с. 359]. На думку П. Куліша такий кордон відлякував від Аравії лихих людей, що дало можливість народу зберегти «волю й правду як святиню» $[5$, с. 358].

Магомета автор наділяє надзвичайною зовнішньою привабливістю, його «голос - водопад, гучний, дзвінкий, гримучий» [5, с. 360]. Він вправний стрілок і наїзник. «А друзі розумом живим його пишались / На нъого надились дівчачі ненъки, / I бігали за ним хлоп'ята молоденъкі» [5, с. 360]. А він дуже часто впадав у сум, у самоті скитався по пустелі: «ЖУрився він, чого його народ кумирам, / Мов господу живому, поклонявся!» [5, с. 361]. Тобто це типовий романтичний герой, який піднімається над натовпом, а це робить його одночасно виключним і самотнім. Проте у випадку з Магометом ми спостерігаємо подолання самотності. Він зумів відповісти на безмежну любов жінки й, можливо, 
саме це допомогло йому бути визнаним за життя й стати тим, ким він став.

Твір написаний про неукраїнські реалії для українців. На це вказують порівняння Мухаммеда з гетьманом, каравана порівнюється з чумацькою валкою. Мухаммед носить жупан, а герої твору іноді називають Україну своєю батьківщиною. Це черговий раз підтверджує, що основним у творі є віднайдення спільних рис християнського й ісламського світів, тих основних точок дотику, які є у Біблії й Корані, щоб довести єдність світових релігій і загальнолюдських цінностей, представлених у них.

Є. Нахлік про поеми «Магомет і Хадіза» і «Маруся Богуславка» зазначає: «Цими творами Куліш хотів відкрити християнсъкій Україні етичні й кулътурні вартові ісламсъкого світу - арабсъкого й тюрксвкого, подолати у свідомості співвітчизників давню антимусульмансъку упередженість, негативний стереотип татар i турків, витворений больклором та літературою передусім романтичною...»[2, с. 205].

Варіант народної думи про Марусю Богуславку був опублікований в «Записках о Южной Русі» (записаний М. Ніговським від бандуриста Миколи Ригоренка). Він і став своєрідним поштовхом для створення поеми П. Куліша «Маруся Богуславка», що була вперше надрукована у Львові в журналі «Літературно-науковий вісник» у 8, 10, 11 і 12 номерах за 1899 рік, уже після смерті письменника. І. Франко у примітці до видання пише, що матеріали були надані проф. Пулюєм: «ми чинимо се задля ї̈ високої поетичної $і$ язикової стійності, не пропускаючи ані змінюючи нічого» [5, с. 641]. Проте відомо, що І. Франко надрукував тільки першу частину поеми, хоч вона мала композиційну завершеність. На сьогодні відомо, що поема повинна була складатися з двох частин по 12 пісень у кожній, але збереглись тільки 13 пісень, інші згоріли під час пожежі на хуторі Мотронівка, як і рукописи перекладу Біблії. Зоряна й Мар'яна Лановик припускають, що дивні обставини зникнення закінчення «Марусі Богуславки» П. Куліша, порушують нову проблему відновлення його творчості: «Однак навряд чи можна з упевненістю сказати, скільки аркушів утрачено, i чому вони були окремо від загального тексту; також незрозуміло, чому П. Куліш не ставив першорядним завданням їх відновити» [1, с. 72]. Тому сьогодні досить складно говорити про цілісність задуму П. Куліша щодо цієї поеми, але й матеріал, що зберігся, є досить інформативним.

Перші сім пісень містять інформацію про родину й дитинство Mapyci, про її викрадення татарами, які вбили батька й спалили рідне 
196Літератури світу: поетика, ментальність і духовністъ. 2020. Bип. 14

село дівчини, тобто в основному сюжет поеми подібний до сюжети думи. Мати Марусі відправляється на пошуки доньки, яка вже живе в Стамбулі у султана Османа II, знаходить її і залишається з донькою. Опис подій перемежовується народними піснями, філософськими роздумами, та описом історичних подій XVII століття. Наступні шість пісень поеми є своєрідним викладом філософсько-релігійної концепції П. Куліша, результат його світоглядних пошуків. Виняток становлять лише вставні сюжети про християнського подвижника ченця Мовчальника і про гетьмана Сагайдачного. Маруся, як і в народній думі, при першій можливості рятує з полону бранців-козаків. Проте в поемі П. Куліша ця подія має іншу інтерпретацію: султан сам влаштовуе утечу коханого Марусі та інших невольників, щоб у такий спосіб продемонструвати коханій своє милосердя й прихилити серце дівчини. Образи султана й Марусі ідеалізовані автором, вони є «носіями вищих загальнолюдсъких ідеалів ісламу й християнства» [2, с. 207]. В уста Османа II П. Куліш вкладає слова, які є знаковими для цього твору й для попередньої поеми: «I над нами, $i$ на вами / той самий создатель. / Всіх народів иар верховний / i законодателъ» [5, с. 510]. Єдність усіх людей, спільність їх інтересів, щодо збереження й передачі нащадкам загальнолюдських цінностей, подібність у основних аспектах усіх релігій - це те, на чому хотів наголосити у «східних поемах» П. Куліш.

Основним, що вирізняе поему П. Куліша «Маруся Богуславка» є той факт, що він на противагу романтичній козакофільсъкій традиції («Сліпим поводирям сліпого гайдамацтва» $i$ нібито «дикого» козачтва), а також традиційній у всіх народів героїзачї чоловічих звершень піднесено до рівня національного й естетичного ідеалу украӥнсъку хуторянку як втілення безкорисливої любові й милосердя» $[2$, с. 206]. Це досить не характерно для літератури того часу. Крім того у поемах «Магомет і Хадиза» і «Маруся Богуславка» П. Куліш одним із перших в українській літературі зобразив поважне та шанобливе ставлення турка й араба до жінки.

За задумом П. Куліша, поема мала б закінчуватись походом Османа II в Україну й Хотинською війною 1620-1621 pp. За задумом П. Куліша, «це мав бути натхненний Марусею похід султана-спасителя для насильницького утвердження в Україні засади вічної любові до ближнього. Таким робом митець прагнув виразити свою поетичну ідею, історіософсъку концепцію (синтез «законів» християнства $i$ ісламу), а не відтворити подї̈ 1620-1621 рр. на Україні. Історичний матеріал - реальні діячі та відносини сусідніх краӥн початку 
XVII ст. - для нъого важсливий остільки, оскільки дае можливості для проповіді гуманізму» [2, с. 208].

Висновки та перспективи дослідження. Отже, твори П. Куліша східної тематики спрямовані на спробу зміни традиційної рецепції Сходу у свідомості українців. Автор апелює до гуманістичних цінностей, якими сповнені Біблія й Коран, тобто до первісних ідеалів християнства й ісламу, наголошуючи на подібності їх основних сентенцій. У «східних поемах» письменник значно випередив свій час, проповідуючи діалог і порозуміння між представниками різних релігій.

Перспективу подальших досліджень убачаємо в окремому монографічному дослідженні рецепції ісламського світу у творчості П. Куліша.

\section{Література}

1. Лановик М.Б., Лановик З.Б. «Східні поеми» П.Куліша на перехресті азіатського містицизму і європейського романтизму. Слово і час. 2019. № 8. С. 56-75.

2. Нахлік Є.К. Пантелеймон Куліш : Особистість, письменник, мислитель: Наукова монографія: У 2 т. / НАН України. Львівське відділення Інституту літератури ім. Т.Г.Шевченка. Серія «Літературознавчі студії. Міжнародний фонд Пантелеймона Куліша. Київ : Український письменник, 2017. Т. 2 : світогляд і творчість Пантелеймона Куліша. Вип. 12. 462 с.

3. Останіна Г.Г. Східний світ у художньому моделюванні Пантелеймона Куліша. Науковий вісник Миколаївського державного університету імені В.О.Сухомлинського. Серія : Філологічні науки. 2013. Вип. 4.12. С. 170-174.

4. Лотоцький А.П. О. Куліш та М.П.Драгоманов у їх листуванні. Прага : Видавництво Українського філологічного товариства у Празі, 1937. 14 c.

5. Куліш П. О. Твори : в 2-х томах / підгот. тексти, упоряд. і склав приміт. М.Л. Гончарук ; авт. передм. М. Г. Жулинський. Київ : Дніпро, 1989. Т. 1. Поетичні твори. 654 с. 